\title{
Hulk-Like Urine: A Case of Green Urine Caused by Flupirtine Intoxication
}

\author{
Maria Vilela $^{1}$, Diana Fernandes ${ }^{2}$, Tatiana Salazar Sr. ${ }^{2}$, Augusto Duarte ${ }^{1}$ \\ 1. Internal Medicine, Centro Hospitalar do Médio Ave, Vila Nova de Famalicão, PRT 2. Internal Medicine, Centro \\ Hospitalar Do Médio Ave, Vila Nova de Famalicão, PRT
}

Corresponding author: Maria Vilela, mariarvilela@gmail.com

\begin{abstract}
Acute intoxications are common causes of admission to the Emergency Department (ED). Flupirtine is a non-opioid analgesic, originally used for acute and chronic pain. Because of several reports of severe liver toxicity, its use was limited to acute pain in 2013 by the European Medicines Agency. Although withdrawn from the European market in March 2018, there are still flupirtine tablets in many households, and most people are unaware of the hazards they might be facing.
\end{abstract}

A 58-year-old man was admitted to the ED after a suicide attempt with $1 \mathrm{~g}$ of flupirtine. He was lethargic and confused but presented no focal neurological deficits or other symptoms, and the rest of his clinical examination was unremarkable. His cerebral CAT and blood chemistry showed no alterations. The only remarkable feature was that he had green urine. After a careful literature search, a similar case was found caused by flupirtine intoxication. After 24 hours of vigilance in the ED, he improved his neurological status and his urine lost part of its greenish color. He was then transferred to the Psychiatric Department, where he presented a complete remission of the clinical alterations. A follow-up check-up showed no permanent deficits.

Review began 12/06/2020 Review ended 12/19/2020 Published 12/28/2020

() Copyright 2020 Vilela et al. This is an open access article distributed under the terms of the Creative Commons Attribution License CC-BY 4.0., which permits unrestricted use, distribution, and reproduction in any medium, provided the original author and source are credited.
Categories: Emergency Medicine, Pain Management, Other Keywords: intoxication, green urine, flupirtine

\section{Introduction}

Flupirtine is a selective neuronal potassium channel opener, with N-methyl-D-aspartate receptor antagonist and type-A $\gamma$-aminobutyric receptor modulatory properties [1]. It was commercially used for the first time in Europe in 1984 for moderate-to-severe cases of acute pain [2]. Because of its muscle relaxant properties, it was frequently used for the treatment of orthopedic pain, migraines, and even neoplastic pain. However, due to an increase in the number of cases reporting liver toxicity after the use of flupirtine, in 2013, its use was restricted, becoming prohibited in Europe in 2018 [3,4].

Because this prohibition in Europe is relatively new, there are still a considerable number of households that have flupirtine tablets. For this reason, we present this case to highlight an extremely rare side effect of flupirtine, which has only been reported once to our knowledge.

\section{Case Presentation}

A 58-year-old man with a known medical history of arterial hypertension and type 2 diabetes mellitus was admitted to the Emergency Department (ED) for prostration in the last 14 hours. According to his wife, he had taken $10100 \mathrm{mg}$ tablets of flupirtine in a suicide attempt. She also reported that in the last three months he had stopped all his usual medications (clopidogrel, metformin, telmisartan, simvastatin), but denied changes in his behavior or other alterations.

On admission to the ED, the patient was lethargic, with a sparse verbal response. His blood chemistry (Table 1) showed no alterations, and his cerebral computerized axial tomography (CAT) (Figure 1) was unremarkable. His urine, which was collected using vesical catheterization, was green in color and without sediment (Figure 2). The laboratory examination of the urine was unremarkable and was negative for drugs (Table 2). 


\section{Cureus}

\begin{tabular}{|c|c|}
\hline Analyte & Result \\
\hline Hemoglobin & $14.7 \mathrm{~g} / \mathrm{dL}$ \\
\hline Hematocrit & $49.3 \%$ \\
\hline Mean corpuscular volume & $88.20 \mathrm{fL}$ \\
\hline Platelets & $237 \times 10^{3} / \mu \mathrm{L}$ \\
\hline Leucocytes & $5.63 \times 10^{3} / \mu \mathrm{L}$ \\
\hline Neutrophils & $66.80 \%$ \\
\hline Lymphocytes & $22.00 \%$ \\
\hline Monocytes & $6.90 \%$ \\
\hline Eosinophils & $3.50 \%$ \\
\hline Basophils & $0.60 \%$ \\
\hline Creatinine & $0.84 \mathrm{mg} / \mathrm{dL}$ \\
\hline Urea & $38 \mathrm{mg} / \mathrm{dL}$ \\
\hline Sodium & $141 \mathrm{mEq} / \mathrm{L}$ \\
\hline Potassium & $4.3 \mathrm{mEq} / \mathrm{L}$ \\
\hline C-reactive protein & $<0.10 \mathrm{mg} / \mathrm{dL}$ \\
\hline Lactate dehydrogenase & $182 \mathrm{U} / \mathrm{L}$ \\
\hline Alanine aminotransferase & $33 \mathrm{U} / \mathrm{L}$ \\
\hline Aspartate aminotransferase & $28 \mathrm{U} / \mathrm{L}$ \\
\hline Total bilirubin & $0,92 \mathrm{mg} / \mathrm{dL}$ \\
\hline International normalized ratio of prothrombin time & 1.1 \\
\hline Activated partial thromboplastin time & $37 \mathrm{~s}$ \\
\hline
\end{tabular}

TABLE 1: Laboratory workup results 


\section{Cureus}

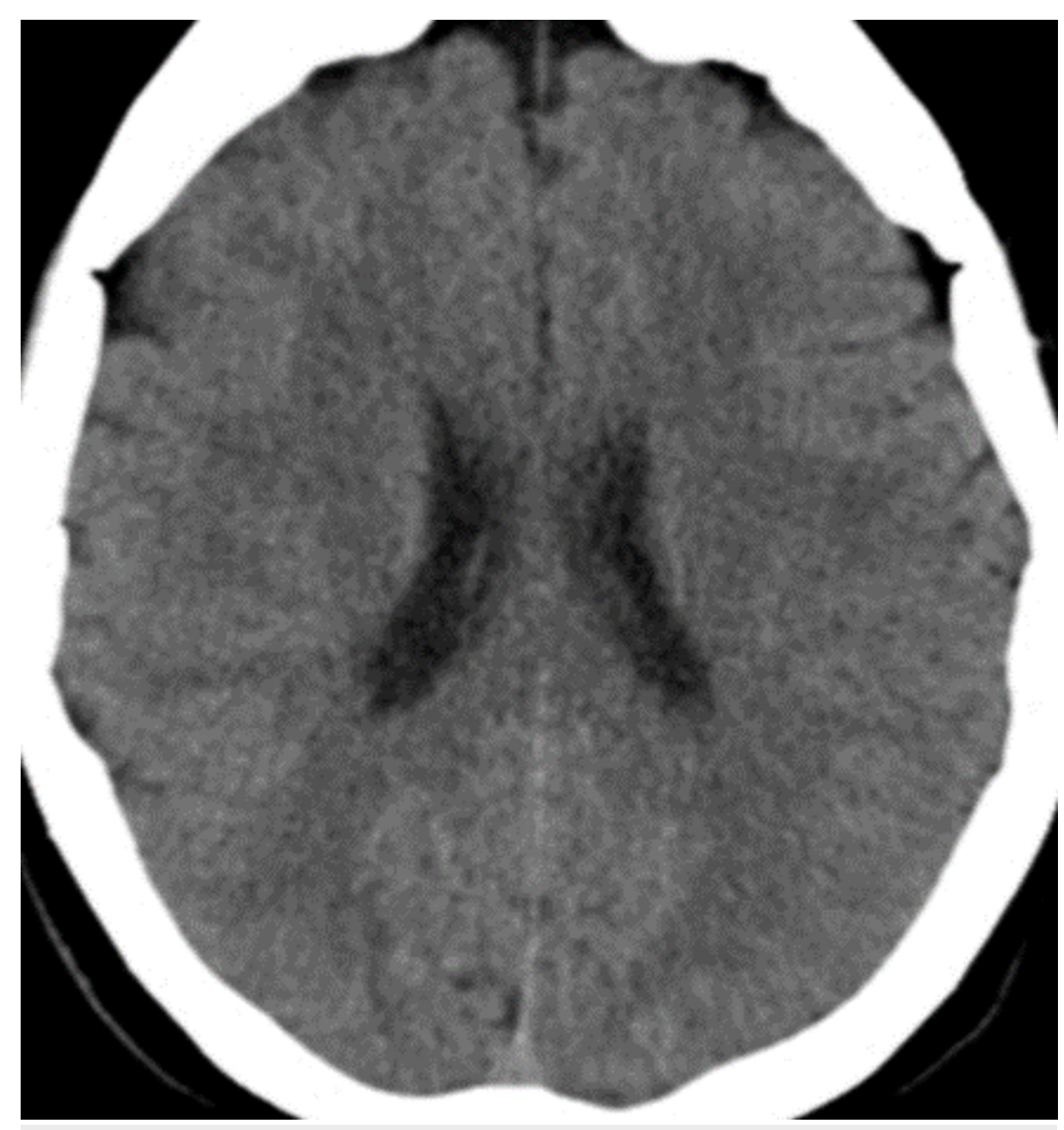

\section{FIGURE 1: Cerebral CAT}

CAT, computerized axial tomography

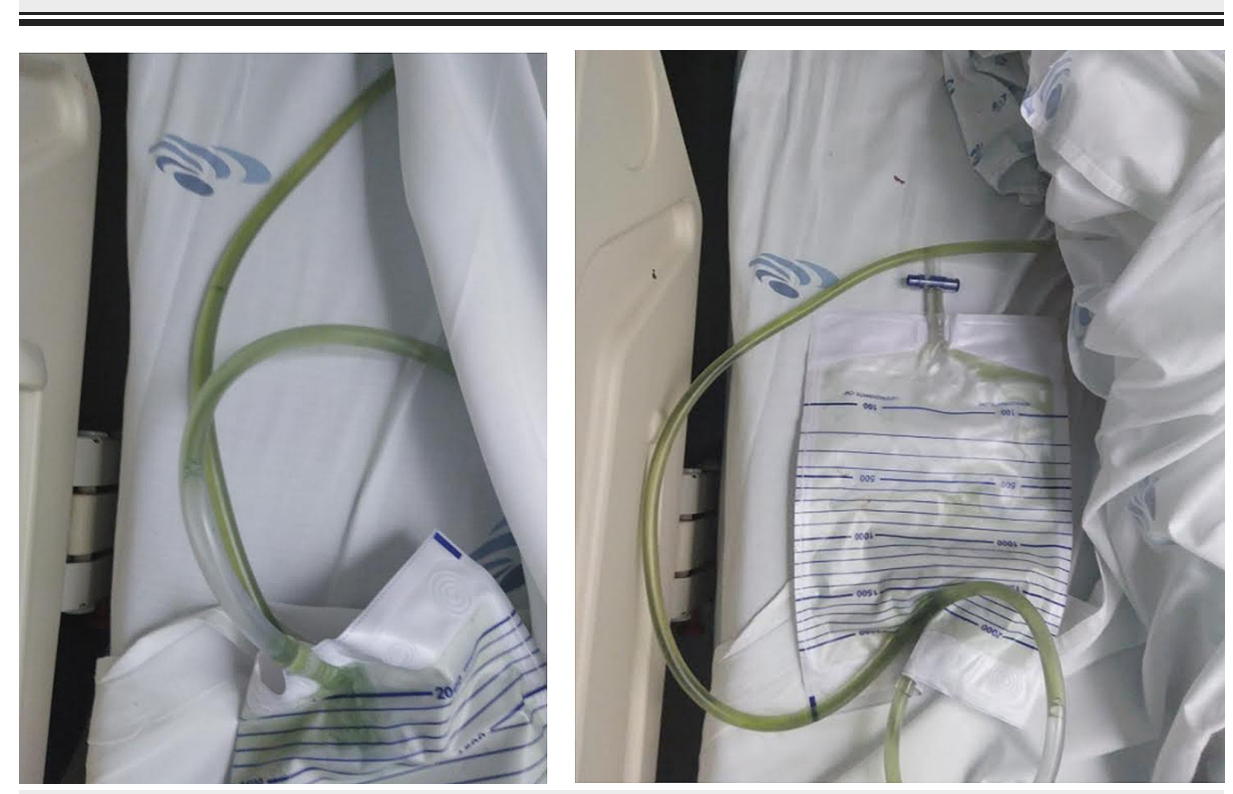

FIGURE 2: Green-colored urine of the patient 


\section{Cureus}

\begin{tabular}{|l|l|}
\hline Drug & Result \\
\hline Amphetamines & Negative \\
\hline Methamphetamines & Negative \\
\hline Barbiturates & Negative \\
Benzodiazepines & Negative \\
Cocaine & Negative \\
Methadone & Negative \\
\hline Opioids & Negative \\
Cannabinoids & Negative \\
Trycyclic antidepressants & Negative \\
\hline
\end{tabular}

TABLE 2: Urine drug screening

The clinical team discussed the case with the National Anti-Poisoning Center and received information that this alteration, namely, the change in the normal color of urine, was plausible in cases of flupirtine intoxication (although with no certainty). The patient was then observed by the Neurology Department. After a careful literature search, a similar case of greenish urine following flupirtine intoxication was found in the literature [5].

He was monitored for the next 24 hours in the ED. Gradually, he became more reactive, and his urine lost some of its greenish color. At the time of discharge from the ED to a psychiatric unit, he was aware, although depressed, and showed no other clinical alterations. A follow-up check-up showed no permanent deficits.

\section{Discussion}

Flupirtine is a potent non-opioid analgesic, which is useful in many cases of moderate-to-severe acute pain. Dependency was only reported in two individuals, and no negative psychological or motor function effects were described. It was also studied as a possible novel treatment for some neurological diseases, namely, Creutzfeldt-Jakob disease, Alzheimer’s disease, and multiple sclerosis [6,7].

However, the prevalence of severe hepatotoxicity could not be ignored, and since 2018, its distribution is prohibited in the European Union. Since only two years have lapsed since 2018, the probability of still viable flupirtine tablets in a common household is remarkably high. Clinicians should be aware of its effects, namely, liver toxicity; although the main reported side effects of flupirtine are dose-dependent, hepatotoxicity is not one of them (Table 3). 


\section{Cureus}

\begin{tabular}{|c|c|}
\hline Side Effects & Prevalence \\
\hline Ataxia & Not described \\
\hline Disturbed sleep & Not described \\
\hline Dizziness & $11 \%$ \\
\hline Drowsiness & $9 \%$ \\
\hline Dry mouth & $5 \%$ \\
\hline Encephalopathy & Not described \\
\hline Fainting & Not described \\
\hline Fatigue & Not described \\
\hline Gastric fullness & $5 \%$ \\
\hline Green urine & Not described \\
\hline Headache & Not described \\
\hline Heartburn & Not described \\
\hline Hepatitis & Not described \\
\hline Increased transaminases levels & Not described \\
\hline Mood elevation & Not described \\
\hline Muscle tremor & $2 \%$ \\
\hline Nausea & Not described \\
\hline Nervousness & Not described \\
\hline Pruritus & $9 \%$ \\
\hline Restlessness & Not described \\
\hline Sedation & Not described \\
\hline Vomit & Not described \\
\hline
\end{tabular}

\section{TABLE 3: Side effects of flupirtine}

The alteration of the normal color of urine to green, as described in this case, immediately led to a comparison to The Incredible Hulk, the green superhero of Marvel Comics. Greenish urine is not a pathognomonic side effect of flupirtine and has been described in cases of consumption or intoxication by some drugs and dyes; it is also a characteristic of some diseases (Table 4) [8-11]. In the Middle Ages, greenish urine was associated with a choleric personality, and in some traditional medicines, namely Persian, it is associated with the dominance of coldness in the body as a result of humoral imbalance and fluid depletion $[8,12]$. 


\section{Cureus}

\section{Green Urine}

Diseases/medical

conditions

Biliverdin; Hartnup disease; familial indicanuria; meconium aspiration; Pseudomonas infection

$\begin{array}{ll} & \begin{array}{l}\text { Amitripyiline; azuresin; bromoform; chlorophyll-containing breath mints; cimetidine; clioc } \\ \text { flutamide; guaiacol; indomethacin; iodochlorhydroxyquin; magnesium salicylate; methoc } \\ \text { phenylbutazone; phenyl salicylate; promethazine (intravenous); propofol; resorcinol; tetrahy } \\ \text { thymol; tolonium; triamterene; zaleplon }\end{array} \\ \text { Dyes } & \text { Diagnex blue; Evans blue; FD\&C Blue No. 1; indigo blue; methylene blue; toluidine blue } \\ \text { Poisons } & \text { Carbamate; imazosulfuron; mefenacet; phenol } \\ \text { Others } & \text { Asparagus; mouthwash overuse }\end{array}$

TABLE 4: Etiology of green urine

\section{Conclusions}

Irrespective of its potency as a non-opioid analgesic, the prevalence of problematic side effects was higher than its benefits. Although not available on the European market anymore, flupirtine is still sold in some Asian countries and could be entering the European Union at any moment. Clinicians must be aware of typical reactions to this drug.

\section{Additional Information}

\section{Disclosures}

Human subjects: Consent was obtained by all participants in this study. Conflicts of interest: In compliance with the ICMJE uniform disclosure form, all authors declare the following: Payment/services info: All authors have declared that no financial support was received from any organization for the submitted work. Financial relationships: All authors have declared that they have no financial relationships at present or within the previous three years with any organizations that might have an interest in the submitted work. Other relationships: All authors have declared that there are no other relationships or activities that could appear to have influenced the submitted work.

\section{References}

1. Szelenyi I: Flupirtine, a re-discovered drug, revisited. Inflamm Res. 2013, 62:251-258. 10.1007/s00011-0130592-5

2. Harish S, Bhuvana K, Bengalorkar GM, Kumar TN: Flupirtine: clinical pharmacology. J Anaesthesiol Clin Pharmacol. 2012, 28:172-177. 10.4103/0970-9185.94833

3. Restrictions in the use of flupirtine-containing medicines . (2013). Accessed: December 1, 2020: http://ema.europa.eu/en/medicines/human/referrals/flupirtine-containing-medicines.

4. Puljak L: Flupirtine, an effective analgesic, but hepatotoxicity should limit its use . Anesth Analg. 2018, 127:309-310. 10.1213/ANE.0000000000003355

5. Hufschmidt A, Krisch A, Peschen I: A girl with headache, confusion and green urine . J Neurol. 2009, 256:1169-1170. 10.1007/s00415-009-5061-2

6. Klawe C, Maschke M: Flupirtine: pharmacology and clinical applications of a nonopioid analgesic and potentially neuroprotective compound. Expert Opin Pharmacother. 2009, 10:1495-1500. $10.1517 / 14656560902988528$

7. Swedberg MD, Shannon HE, Nickel B, Goldberg SR: Pharmacological mechanisms of action of flupirtine: a novel, centrally acting, nonopioid analgesic evaluated by its discriminative effects in the rat. J Pharmacol Exp Ther. 1988, 246:1067-1074.

8. Viswanathan S: Urine bag as a modern day matula. Int Sch Res Notices. 2013, 2013:1-8. 10.5402/2013/215690

9. Rawal G, Yadav S: Green urine due to propofol: a case report with review of literature . J Clin Diagn Res. 2015, 9:3-4. 10.7860/JCDR/2015/15681.6706

10. Greenberg M: Verdoglobinuria. Clin Toxicol (Phila). 2008, 46:485-486. 10.1080/15563650701874629

11. Carpenito G, Kurtz I: Green urine in a critically ill patient . Am J Kidney Dis. 2002, 39:1-5. 10.1053/ajkd.2002.32013

12. Kolouri S, Daneshfard B, Jaladat AM, Tafazoli V: Green urine in traditional Persian medicine: differential diagnosis and clinical relevance. J Evid Based Complementary Altern Med. 2017, 22:232-236. $10.1177 / 2156587216641828$ 